\title{
Oxidation Behavior of FeCr and FeCrY Alloys Coated with an Aluminium Based Paint
}

\author{
Marina Fuser Pillis*, Olandir Vercino Correa, \\ Edval Gonçalves de Araújo, Lalgudi Venkataraman Ramanathan \\ Instituto de Pesquisas Energéticas e Nucleares - IPEN, \\ Av. Prof. Lineu Prestes, 2242, 05508-000 São Paulo - SP, Brazil
}

Received: April 16, 2007; Revised: September 5, 2008

\begin{abstract}
A variety of metallic components rely on properties that are specific to the alloy and its surface. Coatings have been extensively used to protect metallic surfaces from the aggressive effects of the environment to which it is exposed. In this investigation, the high temperature oxidation behavior of a FeCr and a FeCrY alloy coated with an aluminium based paint has been studied. The objective was to form the more resistant alumina surface layer on an aluminium free alloy. Aluminium based paint coated and uncoated specimens of the two alloys were oxidized for up to 200 hours at $1000{ }^{\circ} \mathrm{C}$ in air. The oxidized specimens were examined in a scanning electron microscope coupled to an energy dispersive system and the surfaces were analyzed by X ray diffraction analysis. The aluminium based paint coating increased the oxidation resistance of the alloys, mainly over extended periods. The FeCrY alloy coated with the $\mathrm{Al}$ based paint exhibited the highest oxidation resistance.
\end{abstract}

Keywords: coatings, rare earths, chromium dioxide, alumina

\section{Introduction}

Metallic materials for use at high temperatures in oxidizing environments rely on the formation of a protective oxide layer separating the substrate from the environment to reduce further oxidation of the substrate. Chromium dioxide that forms on chromium containing alloys becomes non-protective upon exposure to oxidizing atmospheres for extended periods at high temperatures. This is due mainly to crack formation in the oxide caused by growth and/or thermal stresses and also due to formation of volatile $\mathrm{CrO}_{3}$. Over 50 years ago it was shown that the addition of small amounts $(<1 \mathrm{wt}$. $(\%))$ of reactive elements, especially rare earths, to chromium dioxide forming alloys increased the oxidation resistance of these alloys by decreasing oxidation rates and by increasing oxide scale adhesion ${ }^{1,2}$. The rare earths have been: a) added as alloying elements or as oxide dispersions; b) implanted in the surface of the alloy; and c) applied as a coating on the surface of the alloy ${ }^{3-7}$.

Chromium is an alloying element in commercial ferritic steels that can be used at temperatures up to $900{ }^{\circ} \mathrm{C}^{8}$. The chromium dioxide layer that forms on these steels confers protection up to $900{ }^{\circ} \mathrm{C}^{8}$. The use of these steels or other chromium dioxide forming alloys at temperatures above $900{ }^{\circ} \mathrm{C}$ is limited due to formation of volatile $\mathrm{CrO}_{3}{ }^{8}$. Consequently, for applications in oxygen rich environments at temperatures in the range $900-1300{ }^{\circ} \mathrm{C}$, aluminium containing alloys or alloys with coatings that form an external $\alpha$-alumina rich layer have been used ${ }^{9110}$. Alumina is thermodynamically more stable than chromium dioxide and it also has a higher melting point. The transport of reactants through alumina is slower, compared to that through chromium dioxide ${ }^{10,11}$. In this context, to protect iron and chromium based alloys for use at high temperatures with alumina surface layers, the use of aluminium based paints have been recommended ${ }^{12,13}$.

This paper presents the oxidation behavior of a $\mathrm{FeCr}$ and a $\mathrm{FeCrY}$ alloy coated with an aluminium paint containing a lower $\mathrm{Al}$ content than those mentioned in references 12 and 13. This paper also presents the oxidation behavior of the $\mathrm{FeCr}$ alloy coated with the same paint containing $1 \mathrm{wt}$. (\%) $\mathrm{Y}_{2} \mathrm{O}_{3}$ and the role of rare earths on the oxidation behavior of $\mathrm{Fe}-\mathrm{Cr}$ alloys.

\section{Materials and Methods}

The alloys $\mathrm{Fe} 20 \mathrm{Cr}$ and $\mathrm{Fe} 20 \mathrm{Cr} 0.7 \mathrm{Y}$ were prepared in a vacuum induction furnace with commercially pure raw materials. The chemical composition of the alloys in weight percent, as determined by $\mathrm{X}$ ray fluorescence spectroscopy is shown in Table 1 . The alloy ingots were forged at $980^{\circ} \mathrm{C}$ and specimens $10 \times 10 \times 2 \mathrm{~mm}$ were cut from these ingots, ground to 220 mesh and degreased in acetone.

Specimens of the two alloys were coated with an aluminium paint containing $9.5 \pm 0.2 \mathrm{wt}$. (\%) $\mathrm{Al}$, as determined by neutron activation analysis and henceforth referred to as $\mathrm{Al}$ paint. A separate paint mixture, referred to as $\mathrm{Al}+\mathrm{Y}_{2} \mathrm{O}_{3}$ was prepared by adding $1 \mathrm{wt}$. (\%) $\mathrm{Y}_{2} \mathrm{O}_{3}$ to the $\mathrm{Al}$ paint. Specimens of $\mathrm{FeCr}$ alloy were coated with this mixture. The two types of paints were applied as a cold spray to cover the surfaces of the specimens. Uncoated and Al paint coated specimens were oxidized in a muffle furnace in air for 20,50 and 200 hours at $1000^{\circ} \mathrm{C}$. All the specimens were weighed before and after oxidation. The mass gain of the specimens as a function of oxidation time was plotted.

The $\mathrm{Al}$ paint, the $\mathrm{Al}+\mathrm{Y}_{2} \mathrm{O}_{3}$ paint and the oxidized specimens were examined in a scanning electron microscope (SEM) coupled to an energy dispersive spectrometer (EDS) to analyze micro regions. The specimens were also analyzed by $\mathrm{X}$ ray diffraction (XRD) analysis.

\section{Results and Discussion}

A small amount of $\mathrm{Al}$ paint was directly placed on a specimen holder and observed in the SEM. The paint with 9.5 wt. (\%) Al consisted of lamellar particles dispersed in an organic vehicle, as shown in Figure 1a. Figure 1b shows an EDS spectrum of the paint and reveals the presence of carbon and oxygen besides aluminium.

A small quantity of $\mathrm{Al}$ paint was heated in a thermobalance in air up to $900{ }^{\circ} \mathrm{C}$ at $5{ }^{\circ} \mathrm{C} / \mathrm{min}$ to determine the volatilization temperature of the organic vehicle in the paint. The mass change curve as a function of temperature is shown in Figure 2. It can be seen that from the room temperature onwards, the paint lost the solvent in it and in the temperature range $300-450{ }^{\circ} \mathrm{C}$, the organic vehicle of the paint volatilized. Beyond about $500{ }^{\circ} \mathrm{C}$, the mass increased and this 
Table 1. Chemical composition of the alloys, as determined by $\mathrm{X}$ ray fluorescence spectroscopy.

\begin{tabular}{lccccc}
\hline \multirow{2}{*}{ Alloys } & \multicolumn{5}{c}{ Elements (wt. (\%)) } \\
\cline { 2 - 6 } & $\mathrm{Cr}$ & $\mathrm{Mn}$ & $\mathrm{Si}$ & $\mathrm{Y}$ & $\mathrm{Fe}$ \\
\hline $\mathrm{FeCr}$ & 19.74 & 0.79 & 0.02 & - & balance \\
FeCrY & 20.05 & 0.64 & 0.12 & 0.69 & balance \\
\hline
\end{tabular}

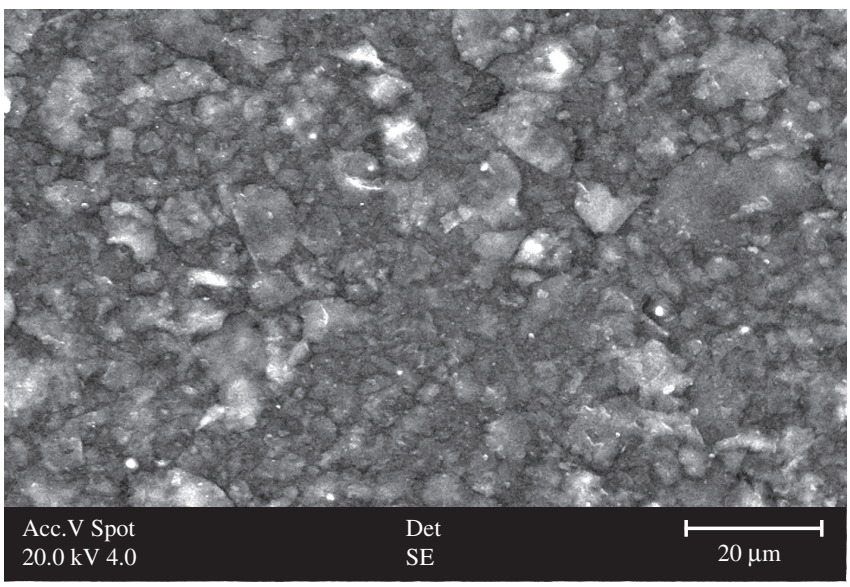

(a)

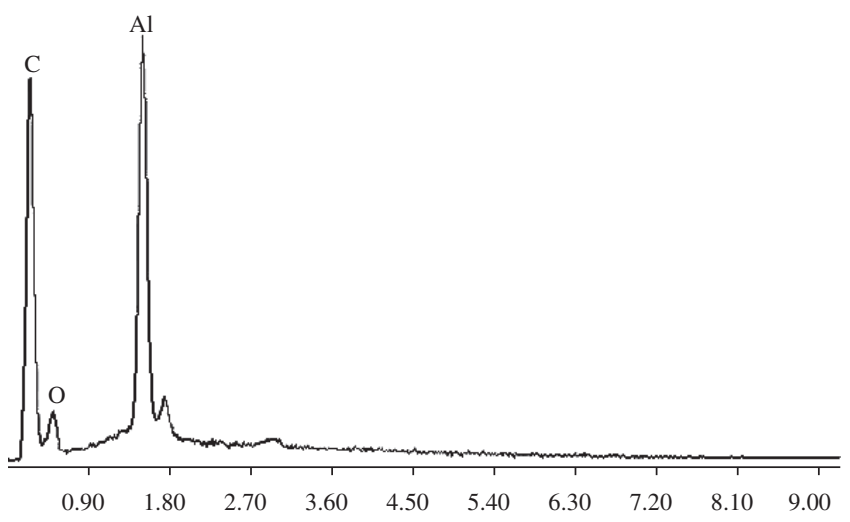

(b)

Figure 1. The morphology: a) revealing lamellar particles and the EDS spectrum; and b) of the aluminium based paint.

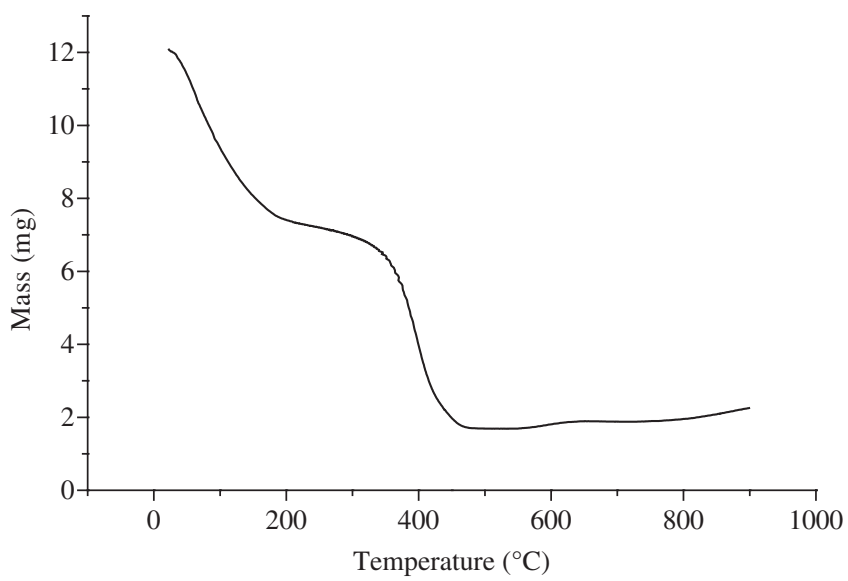

Figure 2. Mass change of the $\mathrm{Al}$ paint as a function of temperature. could be attributed to oxidation of $\mathrm{Al}$ to $\mathrm{Al}_{2} \mathrm{O}_{3}$. This exercise was also carried out in a muffle furnace with a larger quantity of paint, and two temperature plateaus of 15 minutes each at 350 and $450{ }^{\circ} \mathrm{C}$ were used.

XRD analysis was used to determine the composition of the powder residue of the paint following the heating experiments. Figure 3 shows the XRD spectrum of the powder after the initial heating cycle. The phases, $\theta-\mathrm{Al}_{2} \mathrm{O}_{3}$ and $\gamma-\mathrm{Al}_{2} \mathrm{O}_{3}$ were identified besides small quantities of a more stable phase, $\alpha-\mathrm{Al}_{2} \mathrm{O}_{3}$. A large quantity of metallic aluminium was also observed. In the early stages of oxidation of an $\mathrm{Al}$ particle, it forms a surface layer of $\mathrm{Al}_{2} \mathrm{O}_{3}$. Further growth of this layer depends on diffusion of the reactants, $\mathrm{Al}$ and oxygen, through the layer. The fact that aluminium was present in the powder residue of the paint confirmed that the mass gain seen in Figure 2 was due to formation of alumina. The powder residue was used in two further tests to determine the change in composition of the residue with increase in temperature and with time at temperature. In the first test, the powder was reheated in the muffle furnace to $900{ }^{\circ} \mathrm{C}$ and held for 65 hours. In the second test, the powder was reheated to $1000{ }^{\circ} \mathrm{C}$ and held for 65 hours. Figure 3 shows the XRD spectrums of the powders after these tests and reveals that the metallic aluminium transformed to alumina with increase in time of exposure. At the higher temperature, $\alpha-\mathrm{Al}_{2} \mathrm{O}_{3}$ tends to be the predominant phase. On the basis of these results, in subsequent oxidation tests that were carried out in the muffle furnace, the painted specimens were slowly heated up to $1000{ }^{\circ} \mathrm{C}$ and then held at that temperature for up to 200 hours.

Figure 4 shows the oxidation curves of $\mathrm{FeCr}$ and $\mathrm{FeCrY}$ alloy specimens with and without the paint coating. It can be seen that the $\mathrm{Al}_{2} \mathrm{O}_{3}$ layer that formed on the coated specimens decreased the overall mass gain of both alloys. Between the two alloys, the coated $\mathrm{FeCrY}$ alloy exhibited higher oxidation resistance. The difference in oxidation behavior between the two alloys is more evident after prolonged oxidation times. The uncoated $\mathrm{FeCr}$ and $\mathrm{FeCrY}$ alloys did not reveal oxide spalling. The Al paint coating detached from the surfaces of the two alloys whereas the $\mathrm{Al}+\mathrm{Y}_{2} \mathrm{O}_{3}$ paint coating did not.

Figure 5a shows the surface of a specimen of $\mathrm{FeCr}$ alloy oxidized for 200 hours at $1000{ }^{\circ} \mathrm{C}$. The EDS analysis of this specimen, shown in Figure 5b, revealed oxides of $\mathrm{Cr}$ and $\mathrm{Mn}$ on the surface. Figure $5 \mathrm{c}$ is the cross-section of the same specimen. The EDS analysis, shown in Figure 5d, indicated the presence of $\mathrm{Fe}, \mathrm{Cr}$ and $\mathrm{Mn}$. The latter (Mn) was detected on the surface of the oxide layer, as shown by the white arrows. The metal/oxide interface revealed voids and some voids were also seen near the top surface of the oxide layer. Void formation at the interface and in the oxide layer is not an artifact of sample preparation but is characteristic of oxidized iron-chromium alloys and similar findings have been reported ${ }^{14}$. EDS analysis carried out in the oxide layer indicated that this layer was rich in $\mathrm{Cr}$ and the Fe content was less than 1\%. XRD analysis identified the phases, $\mathrm{Cr}_{2} \mathrm{O}_{3}$ and $\mathrm{MnCrO}_{4}$, as shown in the XRD spectrum in Figure 6. The EDS and XRD data indicated that the oxide layer was preferentially $\mathrm{Cr}_{2} \mathrm{O}_{3}$. On top of this layer, $\mathrm{MnCrO}_{4}$ was noted. The presence of $\mathrm{Mn}$ rich phases on the surface of the oxidized specimens indicated that Mn diffused from the alloy to the surface of the oxide. This observation is corroborated by Wild's ${ }^{15}$ findings that showed that $\mathrm{Mn}$ ions diffused 100 times faster than $\mathrm{Cr}$ ions through the $\mathrm{Cr}_{2} \mathrm{O}_{3}$ lattice and formed $\mathrm{MnCrO}_{4}$ on a layer of mainly $\mathrm{Cr}_{2} \mathrm{O}_{3}$.

The surface of a specimen of the FeCrY alloy oxidized for 200 hours at $1000{ }^{\circ} \mathrm{C}$ is shown in Figure 7. The surface is grainier than that of FeCr. EDS analysis indicated the presence of the same elements, $\mathrm{Cr}$ and $\mathrm{Mn}$. XRD analysis revealed the presence of the phases $\mathrm{Cr}_{2} \mathrm{O}_{3}$ and $\mathrm{MnCrO}_{4}$ on the surface of this specimen, similar to that observed on the surface of the $\mathrm{FeCr}$ specimen oxidized under identical conditions and shown in Figure 6. 


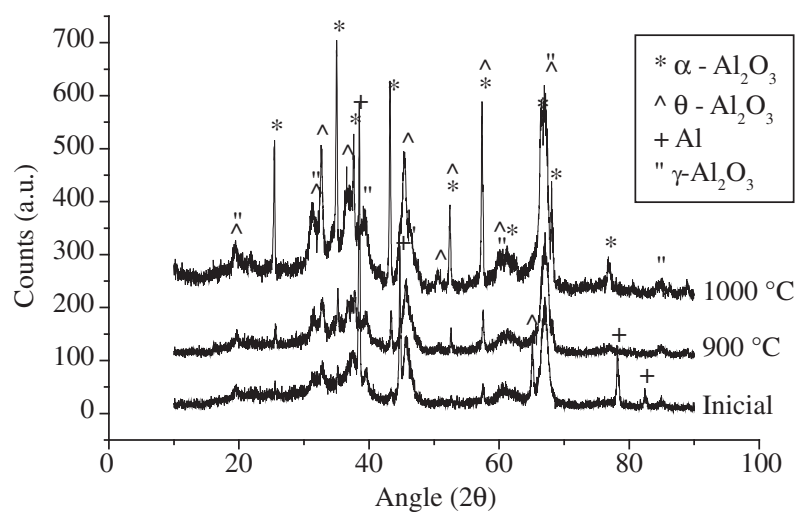

Figure 3. $\mathrm{X}$ ray spectra of the residue of the $\mathrm{Al}$ paint heated to 900 and $1000{ }^{\circ} \mathrm{C}$ for 65 hours.

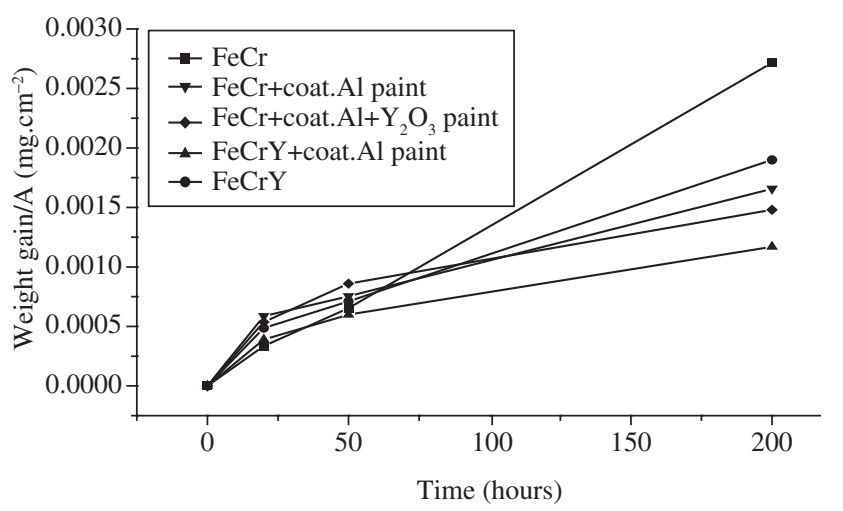

Figure 4. Oxidation mass change curves of the uncoated and the different paint coated alloy specimens as a function of time.

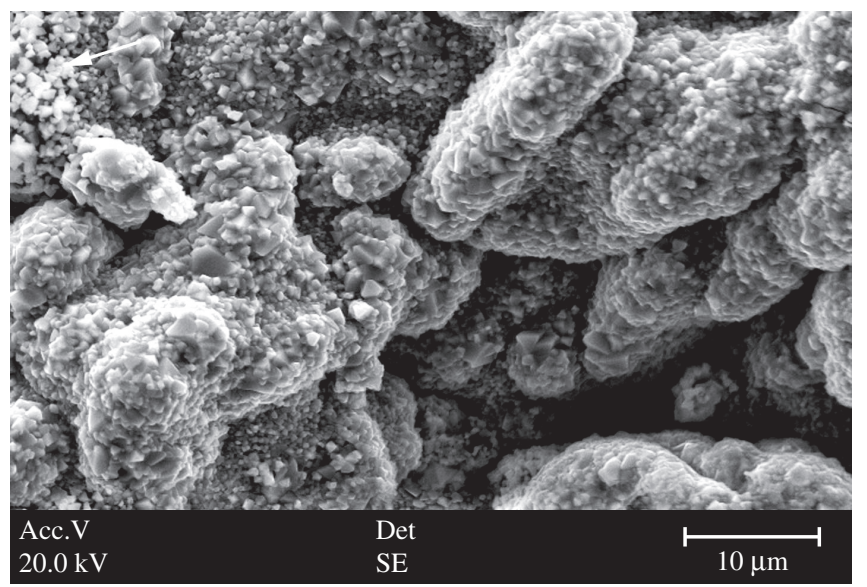

(a)

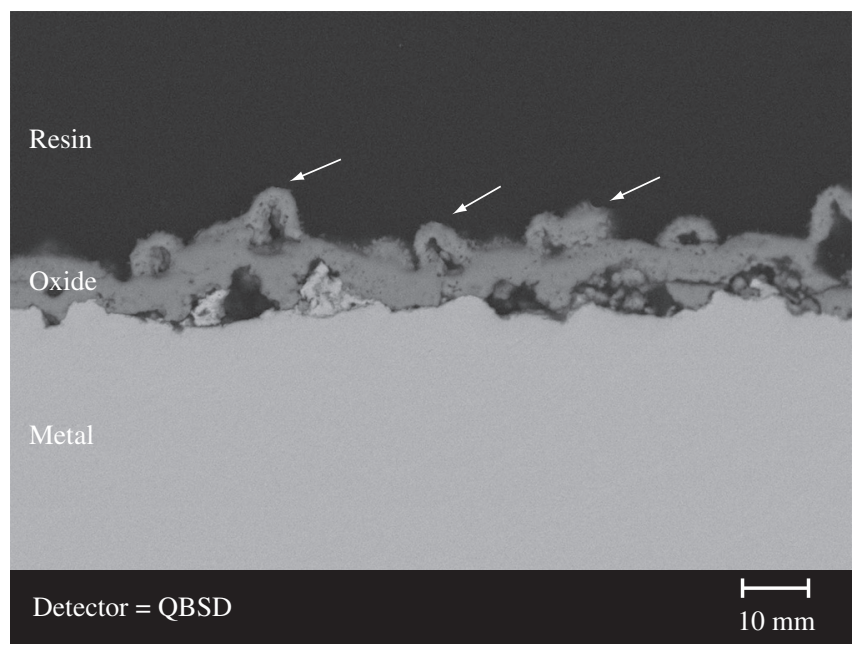

(c)

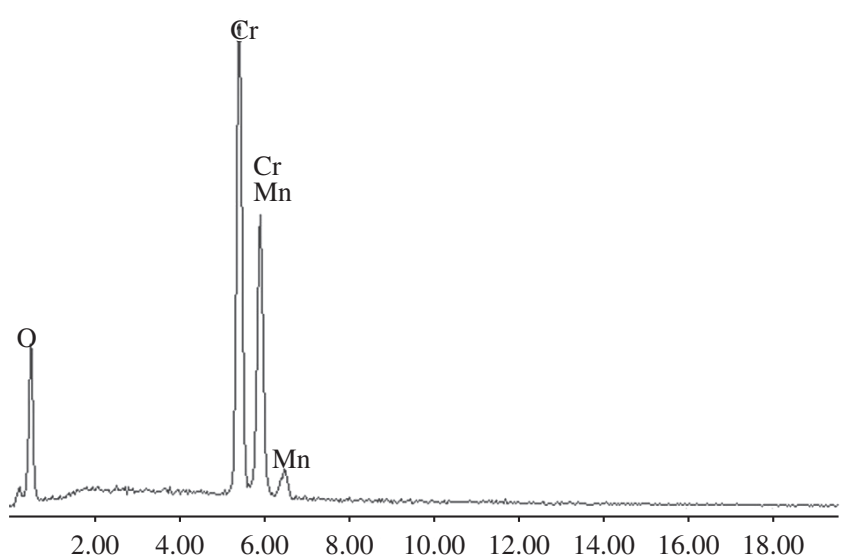

(b)

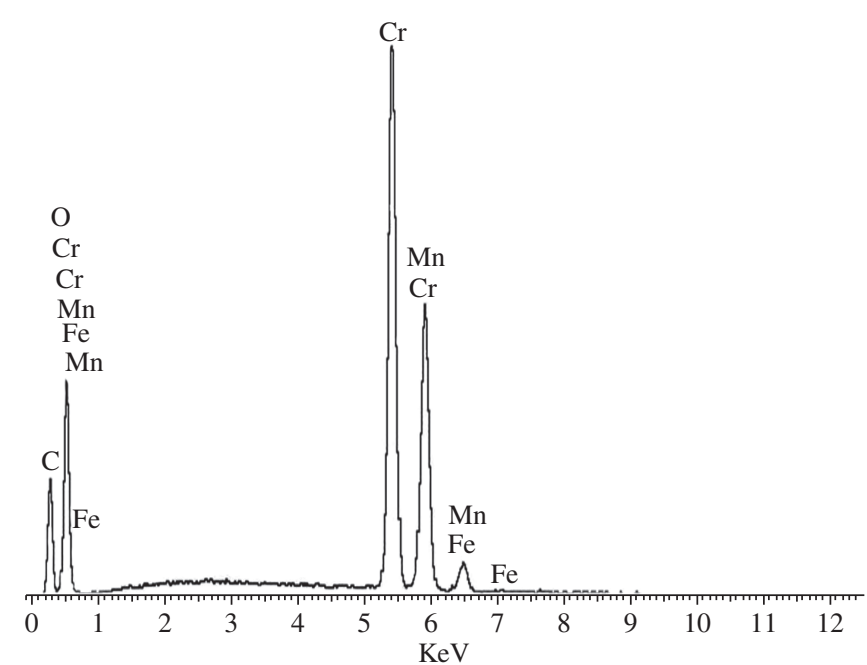

(d)

Figure 5. The surface and composition spectra of the $\mathrm{FeCr}$ specimen oxidized for 200 hours at $1000^{\circ} \mathrm{C}$. a) surface; b) EDS spectrum of the surface; c) cross section; and d) EDS spectrum of the oxide layer.

The surface of a specimen of $\mathrm{FeCr}$ coated with the $\mathrm{Al}$ paint is shown in Figure 8a. The coating detached from the substrate at various regions. In Figure $8 b$, the cross section of this specimen can be seen and it reveals the detached coating at region 1 . The EDS analysis results, shown in Figure $8 \mathrm{c}$, indicated this layer to be rich in Al. The thickness of the coating was approximately $2 \mu \mathrm{m}$. The chlorine peaks in the EDS spectrum were caused by components in the epoxy resin of the specimen mount. EDS analysis carried out in region 2 is shown in Figure 8d. This reveals a $\mathrm{Cr}$ rich oxide, probably $\mathrm{Cr}_{2} \mathrm{O}_{3}$ and traces of $\mathrm{Fe}$. A number of voids can be seen at the metal/oxide interface and in the oxide layer. XRD analysis identified the phases $\alpha-\mathrm{Al}_{2} \mathrm{O}_{3}, \theta-\mathrm{Al}_{2} \mathrm{O}_{3}, \mathrm{Cr}_{2} \mathrm{O}_{3}$ and $\mathrm{MnCrO}_{4}$, as shown in Figure 9. On the basis of the EDS and XRD data it can be 


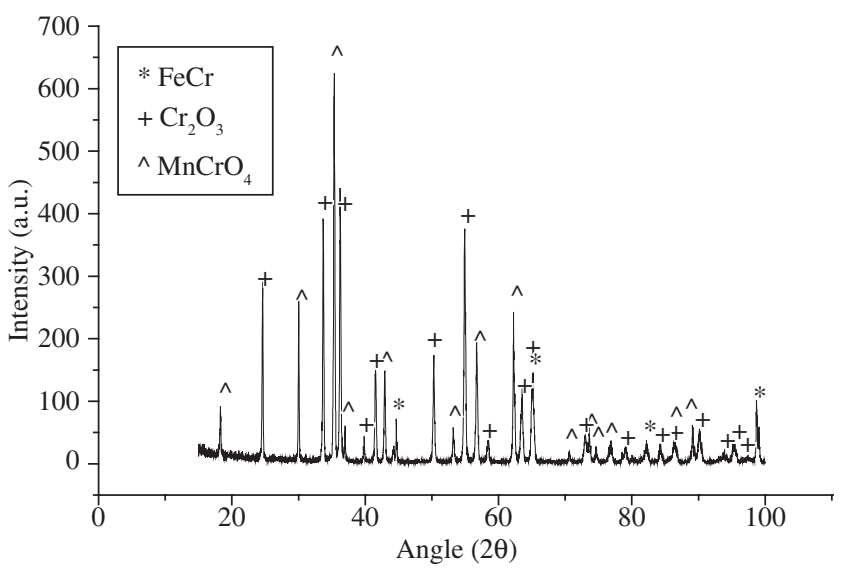

Figure 6. $\mathrm{X}$ ray spectrum of the $\mathrm{FeCr}$ alloy oxidized for 200 hours at $1000{ }^{\circ} \mathrm{C}$.

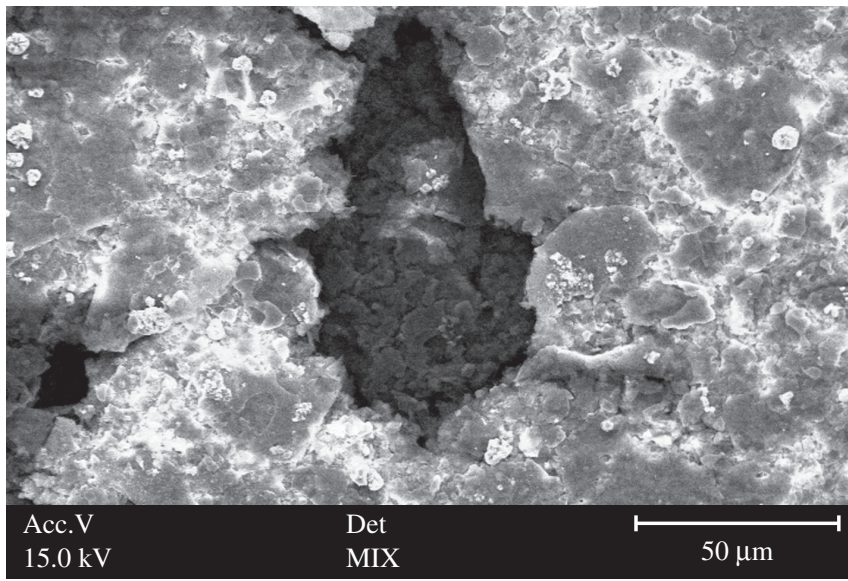

(a)

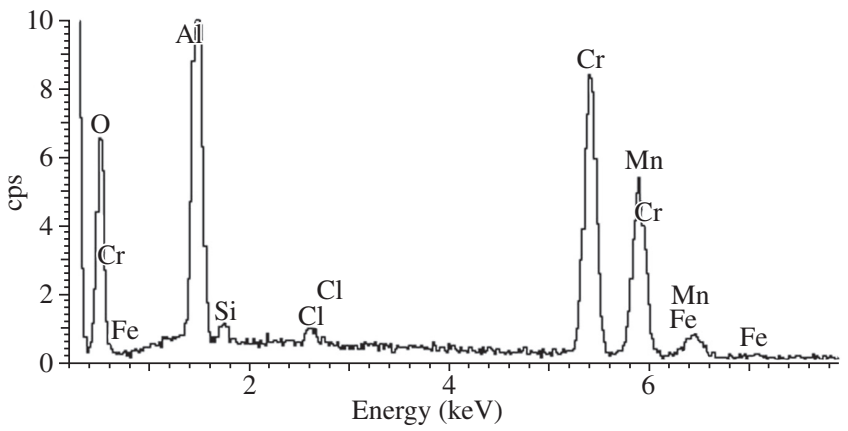

(c)

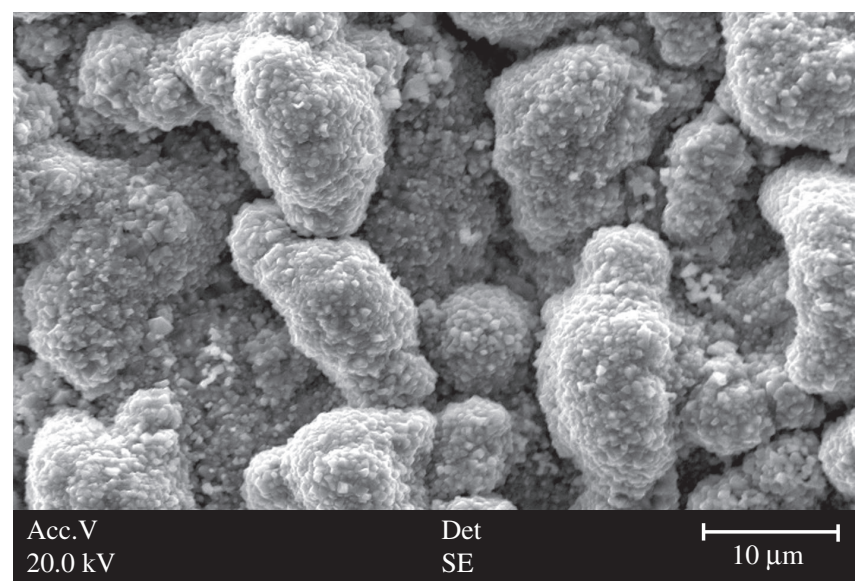

Figure 7. The surface of $\mathrm{FeCrY}$ alloy specimen oxidized for 200 hours at $1000{ }^{\circ} \mathrm{C}$.

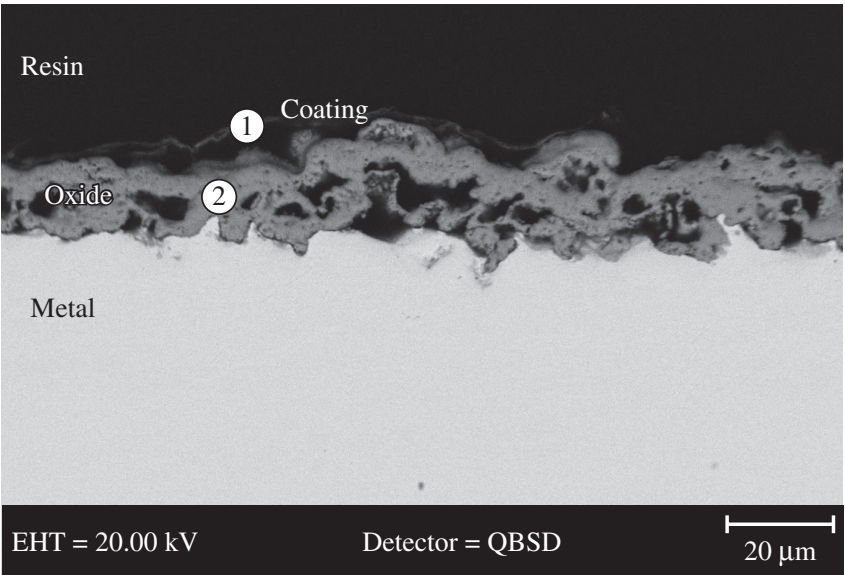

(b)

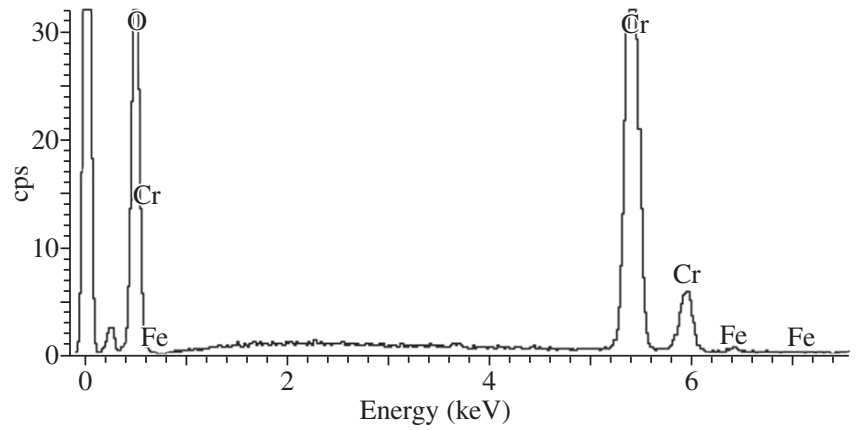

(d)

Figure 8. The surface and composition spectra of the Al coated FeCr specimen oxidized for 200 hours at $100{ }^{\circ} \mathrm{C}$. a) Surface; b) cross section; c) EDS spectrum of region 1; and d) EDS spectrum of region 2.

inferred that the paint layer transformed to $\mathrm{Al}_{2} \mathrm{O}_{3}$, but did not inhibit the formation of a thick layer of $\mathrm{Cr}_{2} \mathrm{O}_{3}$ on the alloy surface.

Figure 10a shows the surface of the $\mathrm{Al}+\mathrm{Y}_{2} \mathrm{O}_{3}$ paint coated $\mathrm{FeCr}$ specimen after oxidation for 200 hours at $1000^{\circ} \mathrm{C}$. EDS analysis at point 1 indicated that the nodules were rich in $\mathrm{Al}$ and probably $\mathrm{Al}_{2} \mathrm{O}_{3}$. Analysis at point 2 on the coating indicated the elements $\mathrm{Al}, \mathrm{Cr}, \mathrm{Si}, \mathrm{Mn}$ and Fe. The cross section of the same specimen is shown in Figure 10b, and reveals that the paint layer transformed to aluminium oxide with particles of $\mathrm{Y}_{2} \mathrm{O}_{3}$ in the middle of the layer (top arrow) and formation of a $\mathrm{Cr}$ rich oxide containing $\mathrm{Mn}$ (bottom arrow). The layer is heterogeneous and its thickness non-uniform. Large voids at the metal/oxide interface and at the oxide/coating interface can be seen. Even though detachment of the paint coating was not observed, the addition of $\mathrm{Y}_{2} \mathrm{O}_{3}$ to the paint did not cause any significant reduction in mass gain. The improved adhesion could be attributed to higher surface roughness.

A region of the surface of $\mathrm{FeCrY}$ alloy specimen under the $\mathrm{Al}$ paint is shown in Figure 11a. EDS analysis of this region, shown in Figure $11 \mathrm{~b}$, indicated the whitened region to be an oxide rich in $\mathrm{Cr}$ and $\mathrm{Mn}$. At 


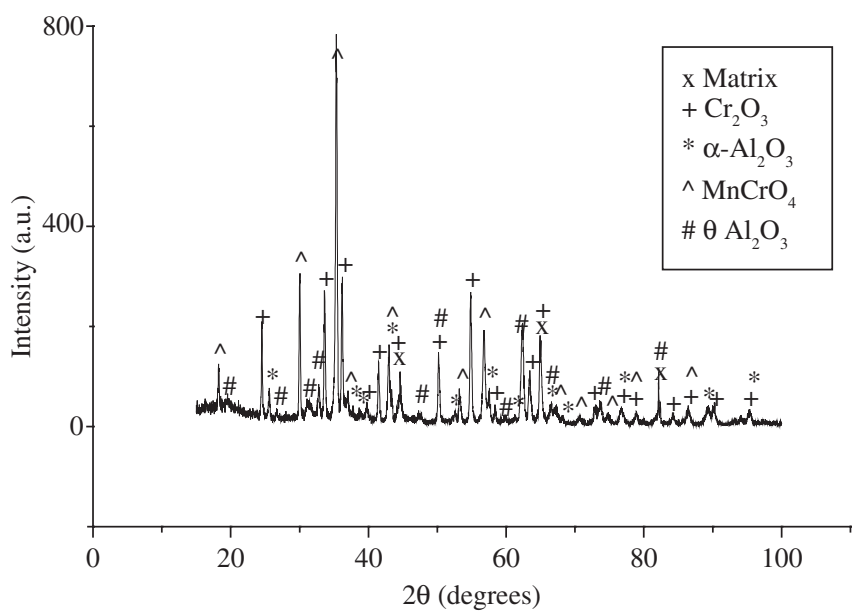

Figure 9. $\mathrm{X}$ ray spectrum of the $\mathrm{Al}$ paint coated $\mathrm{FeCr}$ alloy specimen oxidized for 200 hours at $1000^{\circ} \mathrm{C}$.

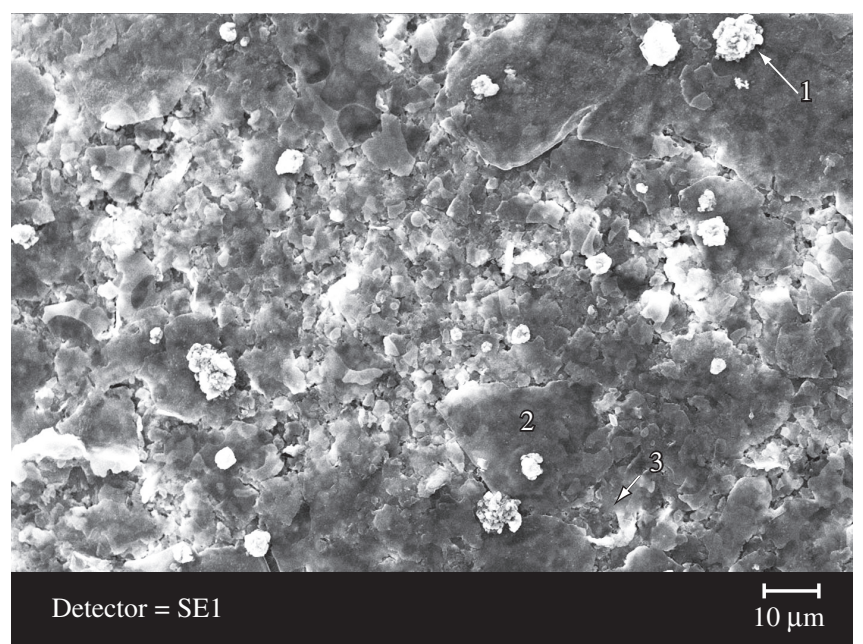

(a)

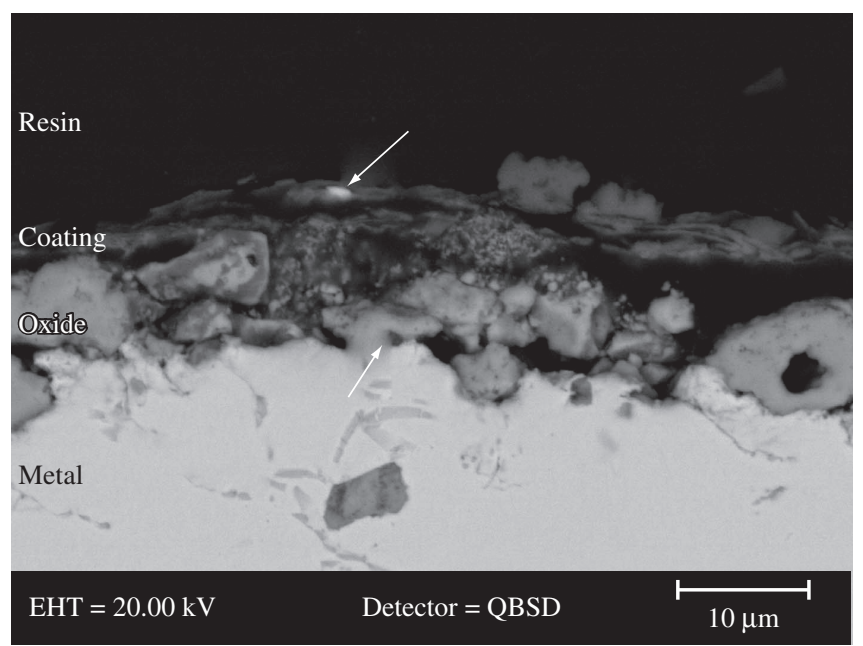

(b)

Figure 10. a) surface; and b) cross section of the $\mathrm{Al}$ paint $+\mathrm{Y}_{2} \mathrm{O}_{3}$ coated $\mathrm{FeCr}$ specimen oxidized for 200 hours at $1000{ }^{\circ} \mathrm{C}$. other regions, the oxide was rich in $\mathrm{Cr}$, probably in the form of $\mathrm{Cr}_{2} \mathrm{O}_{3}$. Figure $11 \mathrm{c}$ is a cross section of the same specimen. The white arrow indicates the coating detached from the substrate. The oxide formed was rich in $\mathrm{Cr}$, as indicated by the EDS spectrum. The thickness of the layer was uniform and revealed voids smaller than those observed in the oxide on the $\mathrm{FeCr}$ alloy specimen. The reduction in the oxide layer thickness and in the number of interfacial voids is due to $\mathrm{Y}$ in the alloy.

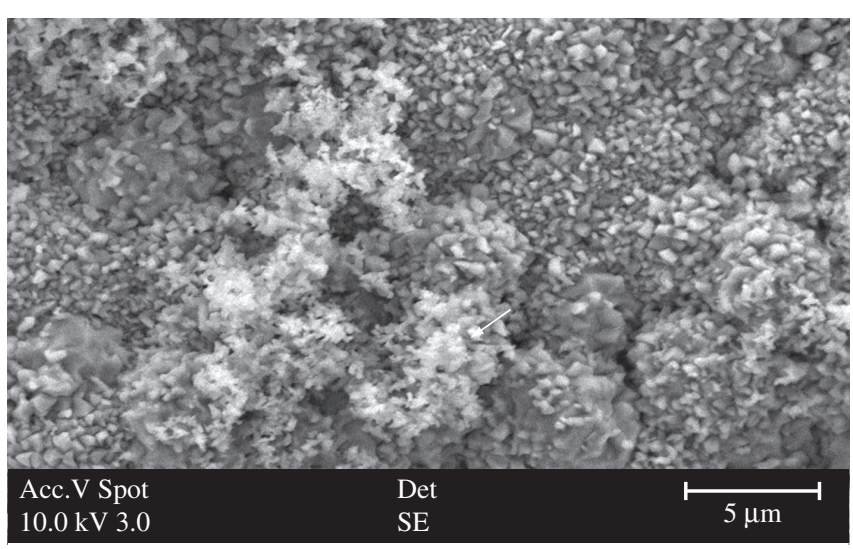

(a)

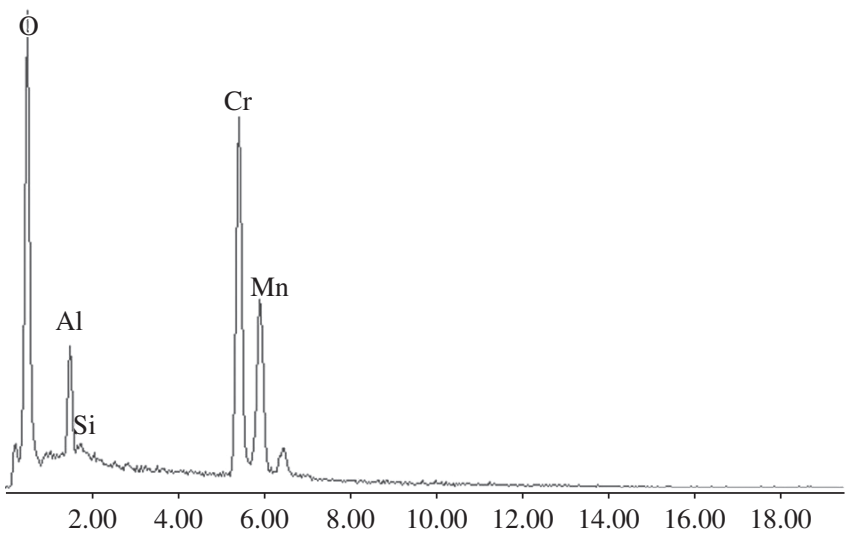

(b)

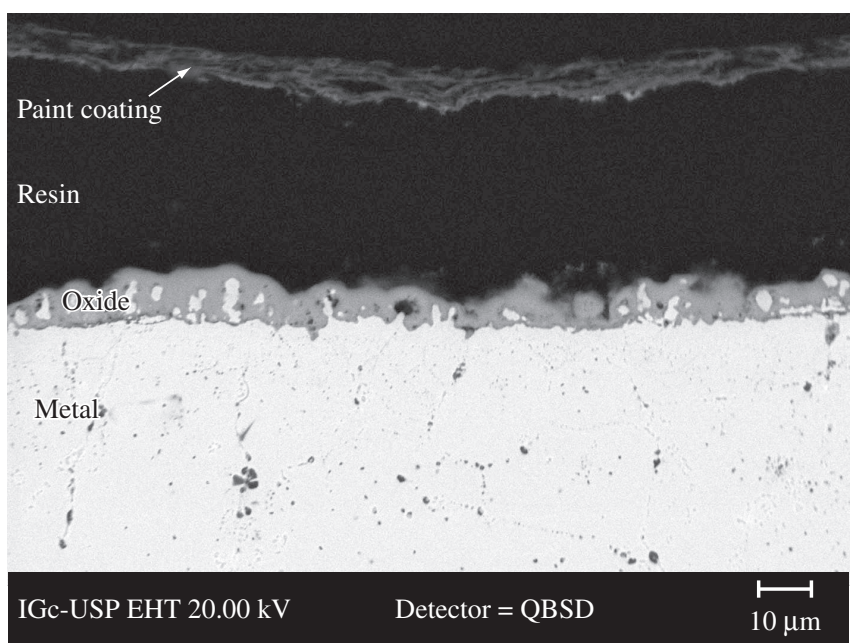

(c)

Figure 11. a) surface; and b) EDS spectrum of the white region (arrow); and c) and the cross section of the $\mathrm{Al}$ paint coated $\mathrm{FeCrY}$ specimen oxidized for 200 hours at $1000{ }^{\circ} \mathrm{C}$. 


\section{General Discussion}

Even though ferritic steels, similar to the FeCr based alloys studied here, are considered to be "chromia formers" the other alloying elements in the steel also oxidize upon exposure to high temperatures. In dry or moist air, the oxides of alloying elements such as $\mathrm{Mn}, \mathrm{Al}$ and $\mathrm{Si}$ and the base metal $\mathrm{Fe}$ form because the oxygen partial pressure in the environment (approximately $0.02 \mathrm{~atm}$ ) is higher than the dissociation pressures of the oxides of these elements ${ }^{16}$. The oxidation of $\mathrm{Fe}$ in the ferritic steels studied here is not considered to be important, due to formation of more protective oxides. Mn oxidizes in the atmosphere used here forming a $\mathrm{Cr}-\mathrm{Mn}$ spinel on top of the chromium dioxide layer ${ }^{17}$. The oxide layer formed on the surfaces of $\mathrm{FeCr}$ and $\mathrm{FeCrY}$ alloy specimens consisted of $\mathrm{Cr}_{2} \mathrm{O}_{3}$ and $\mathrm{MnCrO}_{4}$.

Among the different uncoated and $\mathrm{Al}$ paint coated specimens the $\mathrm{Y}$ containing alloy was most resistant to oxidation. The mechanism more widely accepted in recent years to explain the role of $\mathrm{Y}$ in improving the oxidation resistance of the $\mathrm{Fe}-\mathrm{Cr}$ alloy is based on segregation-diffusion of the $\mathrm{Y}$ ion, both in the alloy and in the surface oxide layer ${ }^{18,19}$. According to this mechanism, the $Y$ ion diffuses into the scale due to the oxygen potential gradient which extends from the gas interface into the substrate. En-route to the gas interface, $\mathrm{Y}$ ions first segregate to the metal-scale interface and then into the scale. The Y ion follows the fastest path to the gas interface, which are the scale grain boundaries ${ }^{20-25}$. The presence of the $\mathrm{Y}$ ion at the oxide scale boundaries results in two effects. The first effect is inhibition of normal outward short circuit transport of alloy cations along scale boundaries due to slow diffusion of the $\mathrm{Y}$ ions. That is, the $\mathrm{Y}$ ion with a larger ionic radius, compared to the ionic radii of the alloy cations, diffuse at a slower rate along the scale grain boundaries and block the transport of the alloy cations. This effectively decreases chromium dioxide scale growth, as observed here on the FeCrY alloy. The second effect is reduction in oxide scale grain growth and this is due to a solute-drag effect of the $\mathrm{Y}$ ions that are at the scale grain boundaries ${ }^{17,26}$. This causes small grained oxides compared to that formed on the surface of $\mathrm{Y}$ free $\mathrm{FeCr}$ alloy specimens. This has also been observed in this investigation. This reduced scale grain size also results in increased scale plasticity ${ }^{18,27}$.

On the $\mathrm{FeCr}$ and $\mathrm{FeCrY}$ alloy surfaces, the $\mathrm{Al}$ paint transformed to $\mathrm{Al}_{2} \mathrm{O}_{3}$ but did not inhibit the formation of a thick layer of $\mathrm{Cr}_{2} \mathrm{O}_{3}$. The addition of $\mathrm{Y}_{2} \mathrm{O}_{3}$ to the $\mathrm{Al}$ paint did not result in any significant reduction in mass gain either. This could be attributed to the more dominant role of $\mathrm{Al}$ than the rare earth oxide dispersion. The $\mathrm{Al}$ paint coated $\mathrm{FeCrY}$ alloy however exhibited higher oxidation resistance. The oxide layer on this Al paint coated FeCrY alloy was uniform and with smaller interfacial voids, due mainly to the conjoint effect of $\mathrm{Al}$ in the paint and $\mathrm{Y}$ in the alloy.

\section{Conclusions}

1. The surface oxide layer formed upon oxidation of the alloys $\mathrm{FeCr}$ and $\mathrm{FeCrY}$ consisted of mainly $\mathrm{Cr}_{2} \mathrm{O}_{3}$ and it also contained $\mathrm{MnCrO}_{4}$;

2. More protective $\alpha-\mathrm{Al}_{2} \mathrm{O}_{3}$ formed in the surface oxide layer of an oxidized $\mathrm{FeCr}$ alloy coated with an $\mathrm{Al}$ based paint containing 9.5 wt. (\%) $\mathrm{Al}$; and

3. The FeCrY alloy specimen coated with the Al based paint revealed increased oxidation resistance.

\section{Acknowledgements}

The authors thank CNPq for the financial support given to the project no: 476019/2003-6

\section{References}

1. Pfeil LB, Griffiths WT. Improvement in heat-resisting alloys. UK Patent No. 459848. 1937.
2. Chevalier S, Larpin JP. Formation of perovskite type phases during the high temperature oxidation of stainless steels coated with reactive element oxides. Acta Materialia 2002; 50(12):3105-3114.

3. Ecer GM, Singh RB, Meier GH. The influence of superficially applied oxide powders on the high-temperature oxidation behavior of $\mathrm{Cr}_{2} \mathrm{O}_{3}$-forming alloys. Oxidation of Metals 1982; 18(1-2):55-81.

4. Stringer J. The reactive element effect in high temperature corrosion. Materials Science and Engineering 1989; 120 A:129-137.

5. Pillis MF, Ramanathan LV. Effect of processing technique on microstructure and oxidation behavior of rare earth oxide dispersion containing steels. Key Engineering Materials 2001; 189-191:322-327.

6. Pillis MF, Araújo EG, Ramanathan LV. Effect of addition of rare earth oxide concentrates on oxidation resistance of SISI 304L. Materials Science Forum 2006; 530-531:99-104.

7. Pillis MF, Ramanathan LV. Effect of alloying additions and preoxidation on high temperature sulphidation resistance of iron-chromium alloys. Surface Engineering. 2006; 22(2):129-137.

8. Birks N, Meier GH. Introduction to high temperature oxidation of metals. London: Edward Arnold; 1983.

9. Hou PY, Stringer J. The effect of surface-applied reactive metal oxides on the high temperature oxidation of alloys. Materials Science and Engineering 1987; 87(part-1):295-302.

10. GrabkeHJ. The role of the interface oxide/metal in the high temperature corrosion resistance of alloys. Materials Science Forum 1999; 294-296:135-138.

11. Pilling NB, Bedworth RE. The oxidation of metals at high temperatures. Journal of the Institute of Metals 1923; 29:529-591.

12. Yagi T, Yamamoto J, Kohara H. Method of forming aluminum coating layer on ferrous base alloy work piece. US Patent No. 4228203. 1980.

13. Rairden III, JR. Process of applying aluminum coatings for non-superstrength nickel-chromium alloys. US Patent No. 4084025. 1978.

14. Guttmann V, Hukelmann F, Griffin D, Daadbin A, Datta S. Studies of the influence of surface pre-treatment on the integrity of alumina scales on MA 956. Surface and Coatings Technology 2003; 166(1):72-83.

15. Wild RK. High temperature oxidation of austenitic stainless steel in low oxygen pressure. Corrosion Science 1977; 17(2):87-104.

16. Menzler NH, Sebold D, Zahid M, Gross SM, Koppitz T. Interaction of metallic SOFC interconnect materials with glass-ceramic sealant in various atmospheres. Journal of Power Sources 2005; 152:156-167.

17. Quadakkers WJ, Piron-Abellan J, Flesh U, Shemet V, Singherser L. Metallic Interconnectors for solid oxide fuel cells-a review. Materials at High Temperature 2003; 20(2):115-127.

18. Ramanathan LV, Pillis MF, Fernandes SMC. Role of rare earth oxide coatings on oxidation resistance of chromia-forming alloys. Journal of Materials Science 2008; 43(2):530-535.

19. Pint BA. Experimental observations in support of the dynamic-segregation theory to explain the reactive element effect. Oxidation of metals 1996; 45(1-2):1-37.

20. Cotell CM, Yurek GJ, Hussey RJ, Mitchell DF, Graham MJ. The Influence of Grain Boundary Segregation of Yttrium in Chromium Dioxide on the Oxidation of Chromium Metal. Oxidation of Metals 1990; 34(3-4):173-200.

21. Versaci RA, Clemens D, Quadakkers WJ, Hussey R. Distribution and transport of yttrium in alumina scales on iron-base ODS alloys. Solid State Ionics 1993; 59(3):235-242.

22. Pint B, Martin JR, Hobbs LW. ${ }^{18} \mathrm{O} /$ SIMS Characterization of the Growth Mechanism of Doped and Undoped $\alpha-\mathrm{Al}_{2} \mathrm{O}_{3}$. Oxidation of Metals 1993; 39(3-4):167-195.

23. Pint $\mathrm{B}, \mathrm{Hobbs} \mathrm{LW}$. The Formation of $\alpha-\mathrm{Al}_{2} \mathrm{O}_{3}$ Scales at $1500^{\circ} \mathrm{C}$. Oxidation of Metals. 1994; 41(3-4):203-233.

24. Pint B, Hobbs LW. Limitations on the use of Ion Implantation for the Study of the Reactive Element Effect in $\beta$-NiAl. Journal of the Electrochemical Society 1994; 141(9):2443-2453.

25. Pint B, Garratt-Reed AJ, Hobbs LW. The Reactive Element Effect in ODS FeCrAl Alloys. Materials at High temperatures 1995; 13(1):3-16.

26. Kingery WD, Bowen HK, Uhlmann DR. Introduction to Ceramics. New York: Wiley; 1976. 457 p.

27. Ramanarayanan TA, Raghavan M, Petkovic-Luton R. The Characteristics of Alumina Scales Formed on Fe-based Yttria-Dispersed Alloys. Journal of the Electrochemical Society 1984; 131(4):923-931. 